\title{
Model Kooperatif Tipe Make A Match dan Pengaruhnya Terhadap Perilaku Sosial Anak Usia 5-6 Tahun di RA Umar Mirza
}

\author{
${ }^{1}$ Nurmawati \\ Universitas Islam Negeri Sumatera Utara \\ email: nurmawati@uinsu.ac.id \\ ${ }^{2}$ Zulfahmi Lubis \\ Universitas Islam Negeri Sumatera Utara \\ email: zulfahmilubis@uinsu.ac.id \\ ${ }^{3}$ Nurmiyanti Hasibuan \\ Universitas Islam Negeri Sumatera Utara \\ email: nurmiyanti201708@gmail.com
}

\begin{tabular}{llll}
\hline Article received & $: 13$ Oktober 2020 & Review process & $: 28$ Desember 2020 \\
Article accepted & $: 7$ Januari 2021 & Article published & $: 8$ Maret 2021 \\
\hline
\end{tabular}

\begin{abstract}
Abstrak
Penelitian ini bertujuan untuk mengetahui pengaruh Model Pembelajaran Kooperatif Tipe Make A Match Terhadap Perilaku Sosial Pada Anak Usia Dini. Penelitian ini berjenis penelitian kuantitatif yang menggunakan desain Quasi Eksperimen tipe Non-Equivalent Control Group Design. Penelitian ini dilaksanakan di RA Umar Mirza Patumbak. Populasi pada penelitian ini yaitu sebanyak 64 orang, dan sampel pada penelitian ini yaitu hanya 20 orang. Teknik sampling yang digunakan yaitu Purposive Sampling. Instrumen pada penelitian ini menggunakan lembar observasi dan rubrik penilaia. Teknik analisis data yang digunakan yaitu uji hipotesis dengan rumus uji-t. Hasil pada penelitian ini membuktikan bahwa: (1) adanya pengaruh model pembelajaran make a match terhadap perilaku sosial anak usia 5-6 tahun di RA Umar Mirza Patumbak; (2) adanya pengaruh metode pembelajaran tanya jawab terhadap perilaku sosial anak usia 5-6 tahun di RA Umar Mirza Patumbak; dan (3) terdapat perbedaan pengaruh antara model pembelajaran make a match dengan metode pembelajaran tanya jawab terhadap perilaku sosial anak.
\end{abstract}

Kata Kunci: Anak usia dini; Model pembelajaran make a match; Perilaku sosial

\section{Abstract}

This study aims to determine effect of Make A Match Cooperative Learning Model on Social Behavior in Early Childhood. This research is a quantitative research that uses a Quasi Experiment design type Non-Equivalent Control Group Design. This research was conducted at RA Umar Mirza Patumbak. The population in this study were 64 people, and the sample in this study was only 20 people. The sampling technique used was purposive sampling. The instrument in this study used an observation sheet and an assessment rubric. The data analysis technique used is hypothesis testing with the t-test formula. The results of this study prove that: (1) there is an effect of the make a match learning model on the social behavior of children aged 5-6 years at RA Umar Mirza Patumbak; (2) the influence of the question and answer learning method on the social behavior of children aged 5-6 years at RA Umar Mirza Patumbak; and (3) there are

Model Kooperatif Tipe Make A Match dan Pengaruhnya Terhadap Perilaku Sosial Anak Usia 5-6 Tahun di RA Umar Mirza Copyright (c) 2021 Nurmawati, Lubis, Hasibuan 
http://jurnaltarbiyah.uinsu.ac.id/index.php/raudhah

e-mail: jurnalraudhah@uinsu.ac.id

p-ISSN: 2338-2163

e-ISSN: $2716-2435$

differences in the influence between the make a match learning model and the question and answer learning method on children's social behavior.

Keywords: Early childhood; Make a match cooperative learning model; Social behavior

\section{A. PENDAHULUAN}

Anak usia dini adalah anak yang membutuhkan rangsangan untuk mencapai pertumbuhan dan perkembangan. Anak sangat membutuhkan adanya pendidikan sejak dini untuk memasuki tahap pendidikan selanjutnya. Termasuk juga perilaku sosial yang akan mendukung perkembangan anak. (Nata, 2018) mengemukakan bahwa perilaku atau kegiatan individu adalah menyangkut hal-hal yang disadari. Perilaku dapat tumbuh dan berkembang menjadi sesuatu yang dimiliki seseorang dan membedakannya dari yang lain. Perilaku sosial pada anak usia dini ialah lebih diarahkan kepada pengembangan sosial pada anak seperti bekerja sama, tolong menolong berbagi dan simpati terhadap teman sebaya.

Hasil pengamatan (observasi) yang dilakukan di RA Umar Mirza Patumbak peneliti melihat terdapat beberapa anak masih memiliki kekurangan dalam bersosialnya. Beberapa anak masih malu-malu dan kesulitan dalam berinteraksi dengan teman-temannya maupun dengan gurunya. Beberapa anak masih terlihat tidak mau bergaul dengan temannya didalam kelas maupun diluar kelas, anak tidak mau bermain bersama teman-temannya didalam kelas maupun diluar kelas. Selain itu terbatasnya media pembelajaran yang digunakan guru dalam proses mengajar disekolah. Penggunaan metode pembelajaran yang digunakan oleh guru kurang efektif. Berdasarkan hasil pengamatan tersebut, terlihatlah bahwa perilaku sosial anak masih kurang di RA Umar Mirza Patumbak belum berkembang.

Berdasarkan permasalahan yang ada sehingga menarik penulis untuk meningkatkan perilaku sosial anak. Dari permasalahan diatas, maka diperlukannya solusi untuk meningkatkan perilaku sosial anak. Maka dari itu perlu diterapkan model pembelajaran yang efektif, adapun model pembelajaran yang digunakan oleh peneliti dan dapat meningkatkan perilaku sosial pada anak yaitu model pembelajaran kooperatif. Pembelajaran kooperatif adalah pemanfaatan kelompok kecil dalam proses pembelajaran yang memungkinkan kerja sama dalam menuntaskan permasalahan. Namun saya memilih

Model Kooperatif Tipe Make A Match dan Pengaruhnya Terhadap Perilaku Sosial Anak Usia 5-6 Tahun di RA Umar Mirza Copyright (c) 2021 Nurmawati, Lubis, Hasibuan 
http://jurnaltarbiyah.uinsu.ac.id/index.php/raudhah

e-mail: jurnalraudhah@uinsu.ac.id

p-ISSN: 2338-2163

e-ISSN: $2716-2435$

model kooperatif tipe make a match untuk diterapkan pada sekolah tersebut dimana model tipe ini yaitu teknik mengajar dengan mencari pasangan melalui kartu pertanyaan dan jawaban yang harus ditemukan oleh anak.

Berdasarkan hasil penelitian diperoleh dari hasil penelitian di RA Umar Mirza Patumbak, pada anak usia 5-6 tahun (kelompok B), tidak mudah bagi guru untuk menjadikan peserta didik aktif dalam mengembangkan potensi dirinya agar dapat berkomunikasi dengan teman sebayanya. Tidak semua pendidik (guru) memahami konsep dari model pembelajaran kooperatif. Mungkin disebabkan oleh kurangnya keinginan dan motivasi untuk meningkatkan kualitas keilmuwan maupun karena kurangnya dukungan sistem untuk meningkatkan kualitas keilmuwan tenaga pendidik.

Salah satu cara mengatasi masalah tersebut adalah dengan menerapkan model pembelajaran kooperatif dimana siswa dapat berkomunikasi dengan baik terhadap teman sebayanya maupun dengan gurunya, bagaimana anak dapat menciptakan kerjasama, interaksi dengan baik terhadap lawan bicaranya. Salah satu model pembelajaran yang peneliti tawarkan ialah model pembelajaran Make A Make (mencari pasangan) terhadap perilaku anak. Menurut (Aswita, 2015) model pembelajaran Make A Make (mencari pasangan) adalah Model pembelajaran make a match adalah model pembelajaran yang menggunakan suatu permainan kartu yang diberi jawaban dan pertanyaan dimana peserta didik mencari jawaban dari pertanyaan yang ada dikartu secara kooperatif. Hal ini sejalan dengan penelitian yang dilakukan oleh (Wardiyanti, 2012) bahwa dengan penerapan model kooperatif make a match dapat meningkatkan kemampuan sosial anak kelompok A. Hal ini dapat dibuktikan dengan meningkatnya kemampuan sosial anak pada setiap siklusnya, yaitu : sebelum tindakan rata-rata kemampuan sosial anak 77,5 kemudian pada siklus I rata-rata kemampuan sosial anak 80,3 pada siklus II rata-rata kemampuan sosial anak 83,9. Berdasarkan uraian di atas maka dilakukan penelitian dengan judul "Pengaruh Model Pembelajaran Kooperatif Tipe Make a Match terhadap Perilaku Sosial Anak Usia Dini di RA Umar Mirza Patumbak".

Model Kooperatif Tipe Make A Match dan Pengaruhnya Terhadap Perilaku Sosial Anak Usia 5-6 Tahun di RA Umar Mirza Copyright (c) 2021 Nurmawati, Lubis, Hasibuan 
http://jurnaltarbiyah.uinsu.ac.id/index.php/raudhah

e-mail: jurnalraudhah@uinsu.ac.id

p-ISSN: 2338-2163

e-ISSN: $2716-2435$

\section{B. METODE PENELITIAN}

Penelitian ini dilakukan di RA Umar Mirza Patumbak. Penelitian ini berjenis penelitian Quasi Eksperimental Design tipe Non-Equivanlent Control Group Design, yang menurut (Sugiyono, 2017) mempunyai kelompok kontrol, tetapi tidak dapat berfungsi sepenuhnya untuk mengontrol variabel-variabel luar yang mempengaruhi pelaksanaan eksperimen. Kelas eksperimen pada penelitian ini yaitu kelas Muzadalifah yang menerapkan model pembelajaran kooperatif tipe make a match, sedangk kelas kontrol yaitu kelas Arafah menerapkan pembelajaran yang biasa digunakan di RA Umar Mirza Patumbak (metode tanya jawab). Pembagian peran kelas tersebut dilakukan dengan undian secarik kertas yang langsung diambil oleh wali kelasnya.

Arikunto dalam (Maisarah, 2017) mengemukakan bahwa populasi adalah keseluruhan subjek penelitian, sedangkan sampel adalah sebagian atau wakil populasi yang diteliti. Populasi pada penelitian ini yaitu 64 orang anak usia 5-6 tahun di RA Umar Mirza Patumbak yang terdistribusi pada 4 kelas (kelas Aqobah sebanyak 7 orang, kelas Safa Marwah sebanyak 12 orang, kelas Muzdalifah sebanyak 20 orang, dan kelas Arafah sebanyak 20 orang). Sampel yang digunakan hanya 40 orang anak usia 5-6 tahun yang terdistribusi pada dua kelas (Muzdalifah dan Arafah), hal tersebut karena quasi eksperimen hanya membutuhkan dua kelas dan dipilih kelas yang mempunyai jumlah siswa yang sama banyaknya.

Pada penelitian ini sesuai dengan tipe Non-Equivanlent Control Group Design, maka dilakukan kegiatan berupa pretes, penerapan perlakuan (treatment), dan postes. Data pretes dan postes kemudian diperoleh dengan menggunakan instrumen penelitian yaitu lembar observasi dan rubrik penilaian. Data yang diteliti yaitu mengenai perilaku sosial anak usia 5-6 tahun yang mempunyai indikator sebagaimana disajikan pada tabel 1:

Tabel 1. Indikator Perilaku Sosial Anak Usia 5-6 Tahun

\begin{tabular}{|c|c|c|}
\hline No & Indikator & Deskriptor \\
\hline \multirow[t]{2}{*}{1} & \multirow{2}{*}{$\begin{array}{l}\text { Menerima sudut } \\
\text { pandang orang lain }\end{array}$} & Menghargai temannya dalam bermain \\
\hline & & Memperhatikan penjelasan dari guru \\
\hline \multirow[t]{2}{*}{2} & \multirow[t]{2}{*}{ Kerja sama } & Bekerjasama dalam melakukan permainan \\
\hline & & Membantu temannya dalam menyelesaikan permainan \\
\hline
\end{tabular}

Model Kooperatif Tipe Make A Match dan Pengaruhnya Terhadap Perilaku Sosial Anak Usia 5-6 Tahun di RA Umar Mirza Copyright (c) 2021 Nurmawati, Lubis, Hasibuan 
http://jurnaltarbiyah.uinsu.ac.id/index.php/raudhah

e-mail: jurnalraudhah@uinsu.ac.id

p-ISSN: 2338-2163

e-ISSN: $2716-2435$

\begin{tabular}{|c|c|c|}
\hline No & Indikator & Deskriptor \\
\hline & & Meminta bantuan kepada temannya ketika menyelesaikan permainan \\
\hline \multirow[t]{3}{*}{3} & \multirow[t]{3}{*}{ Mudah bergaul } & Terampil berkomunikasi \\
\hline & & Bermain dengan temannya \\
\hline & & Senang melakukan permainan dengan temannya \\
\hline \multirow[t]{2}{*}{4} & \multirow{2}{*}{$\begin{array}{l}\text { Perhatian terhadap } \\
\text { orang lain }\end{array}$} & Memberi bantuan kepada temannya yang tidak memiliki crayon \\
\hline & & Mendengarkan ketika temannya bercerita \\
\hline \multirow[t]{2}{*}{5} & \multirow[t]{2}{*}{ Tolong menolong } & Membantu temannya yang terjatuh \\
\hline & & $\begin{array}{l}\text { Antusias membantu temannya ketika kesusahan untuk mencari } \\
\text { jawaban }\end{array}$ \\
\hline
\end{tabular}

Setelah data dalam penelitian ini terkumpul maka selanjutnya dilakukan analisis data dengan menggunakan uji hipotesis. Uji hipotesis yang dilakukan dalam penelitian ini menggunakan rumus uji-t karena penelitian ini terdiri dari dua sampel yang datanya bersifat interval. Rumus uji t yang digunakan yaitu menurut (Jaya, 2018):

$$
t_{\text {hitung }}=\frac{\bar{x}_{1}-\bar{x}_{2}}{\sigma^{2} \sqrt{\frac{1}{n_{1}}+\frac{1}{n_{2}}}}
$$

\section{HASIL TEMUAN DAN PEMBAHASAN}

Pada proses penelitian diperoleh data pretes dan postes dari hasil observasi di kelas eksperimen yang disajikan pada Tabel 2:

Tabel 2. Data Perilaku Sosial Anak Usia 5-6 Tahun di Kelas Eksperimen

\begin{tabular}{|c|c|c|c|c|c|}
\hline \multirow{2}{*}{ Kriteria } & \multirow{2}{*}{ Interval } & \multicolumn{2}{|c|}{ Pretes } & \multicolumn{2}{c|}{ Postes } \\
\cline { 3 - 6 } & & Frekuensi & Persentase & Frekuensi & Persentase \\
\hline BB & $12-18$ & 14 & $70 \%$ & 0 & $0 \%$ \\
\hline MB & $19-29$ & 6 & $30 \%$ & 0 & $0 \%$ \\
\hline BSH & $31-41$ & 0 & $0 \%$ & 13 & $65 \%$ \\
\hline BSB & $42-48$ & 0 & $0 \%$ & 7 & $35 \%$ \\
\hline
\end{tabular}

Model Kooperatif Tipe Make A Match dan Pengaruhnya Terhadap Perilaku Sosial Anak Usia 5-6 Tahun di RA Umar Mirza 
http://jurnaltarbiyah.uinsu.ac.id/index.php/raudhah

e-mail: jurnalraudhah@uinsu.ac.id

p-ISSN: 2338-2163

e-ISSN: $2716-2435$

Tabel 2 menunjukkan bahwa rata-rata anak usia 5-6 tahun di kelas Muzdalifah sebelum menerapkan model pembelajaran kooperatif tipe make a match mempunyai perilaku sosial yang belum berkembang, karena sebanyak 70\% (14 dari 20 orang) memperoleh kriteria belum berkembang (BB), sebanyak 30\% (6 dari 20 orang) memperoleh kriteria mulai berkembang (MB), dan tidak ada yang memperoleh kriteria berkembangan sesuai harapan (BSH) maupun berkembang sangat baik (BSB). Setelah treatment (model pembelajaran kooperatif tipe make a match) diperoleh peningkatan perilaku sosial anak. Pada tabel 2 ditemukan rata-rata anak usia 5-6 tahun mempunyai perilaku sosial yang berkembang sesuai harapan, karena sebanyak 65\% (13 dari 20 orang) memperoleh kriteria BSH, sebanyak 35\% (7 dari 20 orang) memperoleh kriteria BSB, dan tidak ada yang memperoleh kriteria BB maupun MB. Hal tersebut menandakan bahwa model pembelajaran kooperatif tipe make a match memberikan pengaruh terhadap perilaku sosial anak karena telah terjadi peningkatan skor dan kriteria perilaku sosial.

Peningkatan skor dan kriteria perilaku sosial bukan hanya terjadi di kelas eksperimen, tetapi terjadi juga pada kelas kontrol. Data pretes dan postes dari hasil observasi di kelas kontrol disajikan pada Tabel 3:

Tabel 3. Data Perilaku Sosial Anak Usia 5-6 Tahun di Kelas Kontrol

\begin{tabular}{|c|c|c|c|c|c|}
\hline \multirow{2}{*}{ Kriteria } & \multirow{2}{*}{ Interval } & \multicolumn{2}{|c|}{ Pretes } & \multicolumn{2}{c|}{ Postes } \\
\cline { 3 - 6 } & & Frekuensi & Persentase & Frekuensi & Persentase \\
\hline BB & $12-18$ & 18 & $90 \%$ & 0 & $0 \%$ \\
\hline MB & $19-29$ & 2 & $10 \%$ & 0 & $0 \%$ \\
\hline BSH & $31-41$ & 0 & $0 \%$ & 19 & $95 \%$ \\
\hline BSB & $42-48$ & 0 & $0 \%$ & 1 & $5 \%$ \\
\hline
\end{tabular}

Tabel 3 menunjukkan bahwa rata-rata anak usia 5-6 tahun di kelas Arafah sebelum menerapkan metode tanya jawab mempunyai perilaku sosial yang belum berkembang, karena sebanyak 90\% (18 dari 20 orang) memperoleh kriteria belum berkembang (BB), sebanyak 10\% (2 dari 20 orang) memperoleh kriteria mulai berkembang (MB), dan tidak ada yang memperoleh kriteria berkembangan sesuai harapan (BSH) maupun berkembang sangat baik (BSB). Setelah metode tanya jawab dilakukan seperti biasanya sebagai kelas 
http://jurnaltarbiyah.uinsu.ac.id/index.php/raudhah

e-mail: jurnalraudhah@uinsu.ac.id

p-ISSN: 2338-2163

e-ISSN: $2716-2435$

pembanding, maka diperoleh peningkatan perilaku sosial anak. Pada tabel 3 ditemukan rata-rata anak usia 5-6 tahun mempunyai perilaku sosial yang berkembang sesuai harapan, karena sebanyak 95\% (19 dari 20 orang) memperoleh kriteria BSH, sebanyak 5\% (1 dari 20 orang) memperoleh kriteria BSB, dan tidak ada yang memperoleh kriteria BB maupun MB. Hal tersebut menandakan bahwa metode tanya jawab juga memberikan pengaruh terhadap perilaku sosial anak karena telah terjadi peningkatan skor dan kriteria perilaku sosial. Namun untuk mendapatkan generalisasi yang akurat mengenai pengaruh treatment terhadap perilaku sosial anak usia 5-6 tahun maka dilakukan diuji hipotesis menggunakan rumus uji-t.

Rumus uji-t mempunyai asumsi dasar yang harus dipenuhi yaitu data berdistribusi normal dan bervarians homogen, sehingga diuji normalitas dan homogenitas data sebelum melakukan uji hipotesis menggunakan rumus uji-t. Berdasarkan hasil uji normalitas data pretes pada kelas eksperimen diperoleh $\mathrm{L}_{\mathrm{O}}(0,13944)<$ Ltabel $(0,190)$ dan data pretes kelas kontrol diperoleh $\mathrm{L}_{\mathrm{O}}(0,1347)<\operatorname{Ltabel}(0,190)$ dan data postes perilaku sosial anak kelas eksperimen diperoleh $\mathrm{L}_{\mathrm{O}}(0,09556)<\mathrm{Ltabel}(0,190)$ dan data postes perilaku sosial anak kelas kontrol diperoleh $\mathrm{L}_{\mathrm{O}}(0,09611)<$ Ltabel $(0,190)$. Dengan demikian, disimpulkan bahwa hasil pretes dan postes perilaku sosial anak di kelas eksperimen dan kontrol mempunyai data yang berdistribusi normal.

Berdasarkan dari hasil perhitungan uji homogenitas Untuk menguji perbedaan tingkat perilaku sosial anak perlu diketahui apakah data memenuhi asumsi sampel yang berasal dari varians yang homogen atau tidak. maka diperlukan uji kesamaan dua varians. Uji homogenitas observasi pada kelas eksperimen diperoleh Fhitung $<$ Ftabel atau 1,6610 $<$ 2,1682 dan kelas kontrol diperoleh Fhitung $<$ Ftabel atau 1,0280< 2,1682, maka diterima hipotesis nol. Dengan demikian, disimpulkan bahwa perilaku sosial anak di kelas eksperimen dan kontrol mempunyai data yang bervarians homogen.

Setelah diketahui bahwa kelas eksperimen berdistribusi normal dan juga homogen, maka pada tahap selanjutnya yaitu akan dilakukan pengujian hipotesis dengan menggunakan uji-t. Pengujian uji-t ini lakukan hanya pada satu pihak sehingga kriteria untuk menerima atau menolak $\mathrm{H}_{\mathrm{O}}$ adalah jika thitung $>$ pada taraf nyatanya $\alpha=0,05 \mathrm{H}_{\mathrm{a}}$ diterima atau ditolak.

Model Kooperatif Tipe Make A Match dan Pengaruhnya Terhadap Perilaku Sosial Anak Usia 5-6 Tahun di RA Umar Mirza Copyright (c) 2021 Nurmawati, Lubis, Hasibuan 
http://jurnaltarbiyah.uinsu.ac.id/index.php/raudhah

e-mail: jurnalraudhah@uinsu.ac.id

p-ISSN: 2338-2163

e-ISSN: $2716-2435$

Dari hasil uji hipotesis pertama diperoleh nilai thitung $=37,66$ dengan taraf $\alpha=$ 0,05 didapat tabel t pada dt 20 diperoleh nilai tabel $=2,024$. Karena thitung $>$ tabel maka $\mathrm{H}_{\mathrm{O}}$ ditolak dan $\mathrm{H}_{\mathrm{a}}$ diterima. Jadi, disimpulkan bahwa ada pengaruh model pembelajaran make a match terhadap perilaku anak usia 5-6 tahun di RA Umar Mirza Patumbak.

Dari hasil uji hipotesis kedua diperoleh nilai thitung $=7,286$ dengan taraf nilai $\alpha=$ 0,05 yang didapat pada tabel $\mathrm{t}$ dengan $\mathrm{dk} 18$ yang diperoleh dengan nilai tabel $=2,101$. Karena thitung $>$ ttabel maka Ho ditolak dan $\mathrm{H}_{\mathrm{a}}$ diterima. Jadi, dapat disimpulkan ada pengaruh metode pembelajaran tanya jawab terhadap perilaku sosila anak usia 5-6 tahun di RA Umar Mirza Patumbak.

Berdasarkan hasil analisa data telah terbukti bahwa terdapat perbedaan yang penting terhadap perilaku sosial anak yang mengikuti dengan menggunakan model pembelajar make a matchdengan metode pembelajaran tanya jawab. Untuk itu dapat diketahui melalui hasil nilai analisi data dengan menggunakan uji-t yang diketahui bahwa nilai pada kelas eksperimen diperoleh thitung $=37,66$ dengan taraf $\alpha=0,05$ yang didapat pada tabel t pada $\mathrm{dk} 18$ diperoleh nilai $=2,101$. Hasil perhitungan tersebut telah menunjukkan bahwa jumlah thitung $>$ ttabel sehingga hasil penelitian menunjukkan signifikan. Sedangkan pada kelas kontrol diperoleh nilai thitung $=7,286$ dengan taraf nilai $\alpha=0,05$ yang diperoleh pada $\mathrm{t}$ tabel $\mathrm{dk} 18$ diperoleh nilai ttabel $=2,101$. Hasil perhitungan tersebut telah menunjukkan thitung $>$ ttabel sehingga hasil penelitian ini signifikan. Berdasarkan deskripsi data hasil penelitian, maka kelompok anak yang diberikan model pembelajaran make a match telah memiliki perkembangan perilaku sosial anak yang lebih tinggi jika dibandingkan dengan menggunakan metode pembelejaran tanya jawab pada kelompok anak usia 5-6 tahun di RA Umar Mirza Patumbak.

Tabel 4. Data Hasil Uji Hipotesis

\begin{tabular}{|c|c|c|c|l|}
\hline No. & Uji Hipotesis & Thitung & Ttab & Kesimpulan \\
\hline 1. & Kelas Eksperimen & 37,66 & 2,101 & Thitung $>$ Ttabel \\
\hline 2. & Kelas Kontrol & 7,286 & 2,101 & Thitung $>$ Ttabel \\
\hline
\end{tabular}

Model Kooperatif Tipe Make A Match dan Pengaruhnya Terhadap Perilaku Sosial Anak Usia 5-6 Tahun di RA Umar Mirza Copyright (c) 2021 Nurmawati, Lubis, Hasibuan 
http://jurnaltarbiyah.uinsu.ac.id/index.php/raudhah

e-mail: jurnalraudhah@uinsu.ac.id

p-ISSN: 2338-2163

e-ISSN: $2716-2435$

Hasil analisis data dengan menggunakan uji t telah diketahui bahwa nilai postes dari kelas kontrol dan kelas eksperimen nilai thitung $=3,390$ dengan taraf $\alpha=0,05$ didapat pada tabel t pada dk 38 diperoleh nilai thitung $=2,021$. Hasil perhitungan menunjukkan thitung > ttabel maka hasil penelitian signifikan. Berikut sajian dalam bentuk tabel hasil perhitungan nilai hipotesis nilai postes eksperimen dan kelas kontrol.

Tabel 5. Data Hasil Perhitungan Uji Hipotesis Postes

Kelas Eksperimen Dan Kelas Kontrol

\begin{tabular}{|c|c|c|c|c|l|}
\hline \multicolumn{2}{|c|}{ Skor Rata-Rata Postes } & \multirow{2}{*}{ DK } & Thitung & T Tabel & Kesimpulan \\
\cline { 1 - 2 } Eksperimen & Kontrol & & & & \\
\hline 187 & 110 & 38 & 3,390 & 2,021 & Thitung > Ttabel \\
\hline
\end{tabular}

Tujuan ini didasarkan pada rata-rata skor hasil dari perkembangan perilaku sosial anak. Rata-rata nilai posttest anak yang mengikuti model pembelajaran make a match adalah 187 yaitu berada dalam kategori tinggi sedangkan rata-rata nilai posttest terhadap perileku sosial anak pada kelas kontrol adalah 110 yaitu berada pada kategori lebih rendahModel pembelajaran merupakan salah satu faktor penting untuk mencapai suatu keberhasilan dalam proses pembelajaran. Maka dari itu dengan adanya model pembelajaran yang inovatif dapat membantu semangat dan daya tarik siswa untuk belajar sehingga suasana pembelajaran terasa lebih hidup.

Berdasarkan hasil temuan pada penelitian ini telah menunjukkan bahwa ada pengaruh model pembelajaran make a match terhadap perileku sosial anak usia 5-6 tahun di RA Umar Mirza Patumbak. Dapat dilihat dari hasil analisis data dengan menggunakan uji-t, telah diketahui nilai posttest eksperimen diperoleh dengan nilai Thitung $=3,390$ dan didapat pada tabel $\mathrm{t}$ pada df 38 diperoleh $\mathrm{T}$ tabel $=2,021$. Hasil perhitungan menunjukkan Thitung $>$ Ttabel sehingga hasil penelitian signifikan.

Model pembelajaran merupakan salah satu faktor penting untuk mencapai suatu keberhasilan dalam proses pembelajaran. Maka dari itu dengan adanya model pembelajaran yang inovatif dapat membantu semangat dan daya tarik siswa untuk belajar sehingga suasana pembelajaran terasa lebih hidup. Salah seorang tokoh yang sangat berperan dalam teori pembelajaran perilaku yang telah mempelajari hubungan antara 
http://jurnaltarbiyah.uinsu.ac.id/index.php/raudhah

e-mail: jurnalraudhah@uinsu.ac.id

p-ISSN: 2338-2163

e-ISSN: $2716-2435$

tingkah laku dan konsekuensinya mengemukakan bahwa belajar merupakan perubahan perilaku yaitu Skinner. (Trianto, 2014) mengemukakan bahwa prinsip yang paling penting dari teori belajar perilaku Skinner yaitu perilaku berubah sesuai dengan konsekuensi langsung dari perilaku itu. Konsekuensi yang menyenangkan akan memperkuat perilaku, sedangkan konsekuensi yang tidak menyenangkan akan memperlemah perilaku. Di dalam buku (Priansa, 2017) dinyatakan bahwa teori Behaviorisme memandang bahwa manusia sangat dipengaruhi oleh berbagai kejadian yang ada dilingkungannya karena lingkungan tersebut memberikan berbagai pengalaman. Perilaku manusia yang dapat diamati secara langsung merupakan konsekuensi dari perbuatan sebelumnya.

Berdasarkan uairan diatas maka dapat disimpulkan bahwa penerapan model pembelajaran make a match memberikan pengaruh terhadap perilaku sosial anak pada usia 5-6 tahun di RA Umar Mirza Patumbak.

\section{SIMPULAN DAN SARAN}

Hasil penelitian ini memperoleh beberapa simpulan, yaitu: (1) adanya pengaruh model pembelajaran make a match terhadap perilaku sosial anak usia 5-6 tahun di RA Umar Mirza Patumbak; (2) adanya pengaruh metode pembelajaran tanya jawab terhadap perilaku sosial anak usia 5-6 tahun di RA Umar Mirza Patumbak; dan (3) terdapat perbedaan pengaruh antara model pembelajaran make a match dengan metode pembelajaran tanya jawab terhadap perilaku sosial anak. Dengan demikian, maka disampaikan beberapa saran, yaitu: (1) para pendidik perlu diperkenalkan model strategi pembelajaran make a match dan berbagai macam model pembelajaran yang lain agar menarik minat anak dalam belajar; (2) kepala sekolah hendaknya menjadi fasilitator maupun notivator untuk pendidik dan peserta didik berupa pengadaan sarana dan prasarana sehingga dapat membantu anak untuk lebih mudah mengerti dan memahami materi yang disampaikan; dan (3) bagi peneliti, diharapkan dapat memperkaya ilmu pengetahuan tentang anak usia dini pada bidang perkembangan dan kecerdasan anak yang harus diasah oleh pendidik melalui model pembelajaran maupun metode, dan lain-lain.

Model Kooperatif Tipe Make A Match dan Pengaruhnya Terhadap Perilaku Sosial Anak Usia 5-6 Tahun di 


\section{DAFTAR PUSTAKA}

Aswita, E. (2015). Strategi Belajar Mengajar. Medan: Perdana Publishing.

Jaya, I. (2018). Penerapan Statistik Untuk Pendidikan. Medan: Perdana Publishing.

Maisarah. (2017). Hubungan antara Kemampuan Awal Penjumlahan dan Hasil Belajar Perkalian Pada Siswa Kelas II SD. Pembelajaran Inovatif Dalam Mencetak Generasi Yang Profesional Berkarakter Dan Unggul,.

Nata, A. (2018). Psikologi Pendidikan Islam. Jakarta: Raja Grafindo Persada.

Priansa, D. J. (2017). Pengembangan Strategi \& Model Pembelajaran Inovatif, Kreatif, dan Prestatif dalam Memahami Peserta Didik. Bandung: Pustaka Setia.

Sugiyono. (2017). Metode Penelitian Pendidikan Pendekatan Kuantitatif, Kualitattif dan RnD. Bandung: Alfabeta.

Trianto, I. B. (2014). Mendesain Model Pembelajaran Inovatif, Progresif, dan Kontekstual. Jakarta: Prenadamedia Group.

Wardiyanti, M. (2012). Peningkatan Kemampuan Sosial Anak Kelompok A Dengan Penerapan Model Kooperatif Make A Match. Universitas Negeri Surakarta. 